\title{
THE ROLE OF SHARIAH IN THE JUDICIAL SYSTEM OF AFGHANISTAN
}

\author{
Lutforahman Saeed*
}

\begin{abstract}
This article is composed of three main sections. It begins with a short description of the meaning of shariah and figh in the context of Afghanistan, and a review of the historical path of shariah since the arrival of Islam until the era of constitutionalism in Afghanistan. The second section then focuses on the role of shariah in the judiciary after the first constitution was adopted in 1923 until the current constitution. This section reviews the role of shariah within a centralised judiciary and codified law system. The third and final section proceeds to explain the position of shariah in the current judicial system since the 2004 Constitution. It describes how the 2004 Constitution opened a space for the implementation of shariah. It also sheds light on the qualification and appointment of judges before providing a conclusion and policy recommendations.
\end{abstract}

Keywords: shariah, Hanafi school of thought, Afghan judiciary, the Afghan constitutions, legal education in Afghanistan.

\section{Introduction}

This paper focuses on the role of shariah (Hanafi school of thought) in the judiciary of Afghanistan. Since Islam came to the region, religious leaders have worked as judges and implemented laws based on shariah principles. After the first constitution came into force in 1923, shariah principles were codified into laws by the judiciary. While the current 2004 constitution has several provisions dealing with Islamic issues, this research focuses on Article 130, which is directly related to the implementation of Hanafi jurisprudence in the case of a legal lacuna. Having a clearer understanding of the role of shariah in Afghanistan, which has a Muslim population of more than 99.9 per cent, will potentially help strengthen the rule of law and enhance the legitimacy of its judiciary. 


\section{Shariah in the Judicial System of Afghanistan}

Generally, the shariah, particularly of the Hanafi school of thought, has played a significant role in the Afghan judicial system for hundreds of years. ${ }^{1}$ Azizudeen Wakily Popalzaey observed that judgments in Afghanistan have been made according to Hanafi jurisprudence from the era of Imam Abu Hanifa $\left(8^{\text {th }}\right.$ century) up to the present. ${ }^{2}$ Since Islam arrived in this region, Hanafi jurisprudence has been applied in all court cases in Afghanistan. ${ }^{3}$ Rulers and Islamic scholars in Afghanistan have relied on the Hanafi School and have made decisions according to its doctrines because it is followed by around 84 percent of the population. ${ }^{4}$ Historically, due to a lack of codified laws, religious leaders (ulama), shariah faculties, ${ }^{5}$ and Imams have been considered as the main sources of law in the country. Almost all rulers in Afghanistan have had religious leaders (mulla or ulama) from the Hanafi school working for them as court judges. ${ }^{6}$ The first article of the second Afghan Constitution stated that the official religion of Afghanistan is the holy religion of Islam and the official school of thought is the Hanafi school. ${ }^{7}$

\section{Shariah and Figh in the Context of Afghanistan}

Shariah and fiqh are controversial terms in Afghanistan. There are two perspectives among Afghan legal experts regarding the meaning of these two terms: (1) Shariah and fiqh are the same and carry the same meaning, and (2) the two refer to different entities. To most Afghans, and some Afghan legal experts, the former holds true. ${ }^{8}$ They believe that the shariah and fiqh are synonymous and interchangeable and that there is no difference whether a decision has been made according to the shariah or fiqh.

On the other hand, some Afghan legal scholars differentiate between the two and believe that each of them covers a separate scope of knowledge in the field of Islamic legal science. ${ }^{9}$ According to them, the concept of shariah is much broader than fiqh. Shariah, like a big circle, includes legal, moral, and faith issues. Fiqh, however, is a smaller circle within the shariah and is limited to ahkam (legal orders). In other words, fiqh is a subcategory of shariah. According to them, fiqh is legal opinion inferred from shariah sources, mainly the Quran and Sunnah, and is therefore subject to change in relation to time and place. This perspective appears to be closer to the position of other Islamic scholars outside Afghanistan, especially from Arab countries. This perspective has roots in the Afghan academic environment, especially among shariah faculties, where most professors have a background in Islamic studies from Arab countries. 
In practice, most Afghans, including many judges and lawyers, favour the first point of view and do not differentiate between the two terms, commonly considering them to be the same. Therefore, I will use the terms shariah and figh interchangeably in this research, following their common usage in Afghanistan.

\section{Historical Background of the Role of Shariah in the Afghanistan Judiciary}

The legal history of Afghanistan indicates that shariah principles were the main source of law, and that religious leaders have worked as judges and made decisions accordingly. In the past, there were no state-established court systems for many centuries, and religious leaders presided over legal cases either from their houses or in mosques. However, in the early $11^{\text {th }}$ century, Sultan Mahmood Ghaznavi $^{10}$ built a big mosque in Ghazni city and named it Arowsul Falak. Besides this mosque, he built a madrasa (religious school) and provided facilities for Islamic scholars to stay and teach there. Notably, for the first time, there was a specific place for a court and its legal staff. Nevertheless, the judgment process was often a one-off affair with no right of appeal or review by a supreme court. ${ }^{11}$

Likewise, in the era of Timuryan (the Timorese), at the time of the successors of Genghis Khan, under King Shah Rukh (1376 - 1447), son of King Timor, shariah was the main source of law with religious leaders taking the role of court judges. King Shah Rukh initially established courts operating under two systems: in one, decisions were made based on Mongolian customary law and a code of conduct (Yasa) dating back to Genghis Khan; ${ }^{12}$ in the second, decisions were based on the Islamic shariah. Yasa was the main source of law for some time in Genghis Khan's territory, and he severely punished its violators. After some time, King Shah Rukh revoked the Yasa, and only shariah law remained. The highest rank in the judiciary was called sudoor, and Islamic scholars played a substantial role in the government. The Hanafi school was the primary source of law. ${ }^{13}$

Nevertheless, due to the absence of codified laws, the opinions of Islamic scholars were still the main source of law when Ahmad Shah Durrani (17221773) established a modern Afghan state in $1747 .{ }^{14}$ Qualified religious leaders still worked as judges, but they first had to pass an exam and meet certain qualifications. Imam Darbari, a courtier and spiritual leader, would first examine and then introduce potential judges to King Ahmad Shah before they were appointed as courts judges. It was also during Durrani's reign that the new position Khan Ulum or Qadi al-Quddat (Chief Justice) was created, which presided in the capital city of Qandahar and took charge of the judiciary branch 
of the King's government. Among the chief judges was the famous religious scholar, Mulla Idrees, who had eight assistants and a clerk. ${ }^{15}$ At that time, a collection of scholarly legal opinions (fatwas) based on the Hanafi school of thought, and entitled Fatawa Ahmad Shahi, was written in the Pashto language by the famous Afghan scholar Mawlawi Abdullah Qandahari. It was later published in 1904 and become the code of law for judges. ${ }^{16}$ The Hanafi school continued its role as the primary source of law beyond the time of King Ahmad Shah Durani.

King Ahmad Shah Durani's son, Timor Shah, moved from Qandahar to Kabul, making the latter capital of his territory in $1776 .{ }^{17}$ A court was established in the western part of Kabul city and an Islamic scholar, Mawlawi Abdulrahim, was appointed as chief justice. Timor Shah established two courts, Bagh-e Shah (King's garden) and Bagh-e Qadi (Judge's Garden), for people to submit their petitions for justice. ${ }^{18}$ In addition to the courts, there was another place called Tasbih Khana (House of Praise) where religious scholars and judges conducted research, met to discuss legal topics, and found solutions to new legal problems in accordance with the shariah. ${ }^{19}$ Timor Shah's successors, including Shah Zaman, Shah Mahmood, Shah Shuja, Amir Dust Muhammad Khan, and Amir Shir Ali Khan, continued to adopt the Hanafi school of jurisprudence as the main source of law. ${ }^{20}$

For the first time in the history of Afghanistan, Amir Abdul Rahman Khan (r.1891-1901) initiated reform in the judicial sector of the government. ${ }^{21}$ Before Amir Abdul Rahman Khan, there were two main sources of law: Islamic law and local custom (urf). There was no central court system, and judges worked either from their houses or in mosques. In addition to shariah laws, disputes were settled based on custom, as long as there were no apparent contradictions between them. There were no guidelines or regulations for the judges. ${ }^{22}$ Abdul Rahman Khan was the first to centralise the court system and appoint judges paid by the government. The judges worked full time in their offices like other state employees and they were prohibited from conducting any other business, including teaching in madrasas (religious schools). These judges were chosen from among Islamic scholars or ulama who had a specific level of knowledge in Islamic jurisprudence. ${ }^{23}$

At that time, Afghan religious scholars were mostly trained in India and Central Asia (especially in Samarqand, Bukhara, and Tashkent). ${ }^{24}$ Since judges were chosen from among Islamic scholars who were teaching in religious schools, the decision was seen by some as a revolutionary decision that reduced the participation of ulama in the business of teaching. This change was part of a set of rules codified in a book called Asas al-Quzzat, ${ }^{25}$ written by the famous Afghan Islamic scholar, Ahmad Jan Alokozai, in 1885 in the Dari language. ${ }^{26}$ 
This was a significant turning point because the main language of Islamic jurisprudence, particularly legal texts, had traditionally been Arabic. Even most non-Arab scholars wrote their books in Arabic.

By 1901, judges were government employees with a dedicated workplace and role. ${ }^{27}$ This was a positive development and limited concerns about corruption when the judges operated from more informal spaces, such as their homes or mosques. ${ }^{28}$

\section{The Role of Shariah after the 1923 Constitution}

The first constitution, "Nezam Namah Asasi", was approved on 2 March 1923, during the reign of King Amanullah Khan. In it, Islam was declared as the state religion and the Hanafi School as the official school of jurisprudence in the state of Afghanistan. ${ }^{29}$ The constitution also gave more power to the King by declaring him venerable and beyond any accountability. ${ }^{30}$ There was no separation of powers; the King held all legislative power, which in effect limited the power of tribal and religious leaders. The constitution allowed only the state courts to hear a case; it prohibited any other institutions like religious courts or any informal justice systems from presiding over a case. ${ }^{31}$

After the Asas al-Quzzat adopted by King AbdulRahman, the second legal book written in the Dari language was the Tamassuk al-Quzzat al-Amaniyah, enacted by Amanullah Khan in 1921. ${ }^{32}$ This book was a set of legal opinions collected from different sources from the Hanafi School with a primary emphasis on hudud crimes. It was written in the Dari language in an effort to unify the Hanafi School sources, which were mostly in Arabic, thus providing judges with a common reference. ${ }^{33}$

The spirit of Article 130 of the current 2004 constitution can be traced back to the Tamassuk. It was mentioned therein that when there is no provision regarding a case, any legal decision should be suspended and sent to the Ministry of Justice. The Ministry of Justice would then inform the King and the Ulama Council would convene to discuss the matter in light of the Hanafi School. After a decision had been made, the King would sign it before it was added to the book. ${ }^{34}$ This approach shows that the codification of Hanafi jurisprudence remains an ongoing process and is regularly updated.

After King Amanullah, King Nader Shah, on 31 October 1931, continued the reform process by adopting the second constitution, entitled Ausul Asasi Dawlat Aleyah Afghanistan. The new constitution set an additional condition to be the King; besides being a Muslim, the King must be a follower of the Hanafi School of thought. ${ }^{35}$ Additionally, it was further stated that official 
courts were the only place to initiate a legal case, and the Hanafi School must be applied in all cases. ${ }^{36}$

Ideas regarding the superiority of secular legislation over the shariah were first raised during the Nationwide Grand Council (Luya Jirga) in 1964. A revolutionary change happened when the Jirga members debated a new Afghan constitution. Article 69 of the 1964 Constitution indicates:

Law is a resolution passed by both houses, and endorsed by the King. In the area where no such law exists, the provisions of the Hanafi Jurisprudence of Shariah of Islam shall be considered as law. ${ }^{37}$

For the first time, state law was the primary source of law in all cases, and shariah provisions served only as a backup if there was a gap in the state law. According to Louis Dupree, Article 102 of the 1964 Constitution is the most important clause in the document because it shifts towards secularism. ${ }^{38}$ The 1964 Constitution marked a major shift in the Afghan legal system because for the first time the supremacy of the state law over shariah was constitutionally enshrined. Article 102 of the 1964 Constitution states:

The courts in the cases under their consideration shall apply the provisions of this constitution and the laws of the state. Whenever no provision exists in this constitution or the laws for a case under consideration, the courts shall, by following the basic principles of the Hanafi jurisprudence of the Shariah of Islam and within the limitations set forth in this constitution, render a decision that in their opinion secures justice in the best possible way. ${ }^{39}$

There was a hot debate between conservative religious leaders and Westerngraduated scholars regarding the supremacy of law. Mawlawi Ghulam Nabi Kamawi, a famous religious leader, represented the conservative party while his son, Dr Muhammad Moosa Shafiq, who studied in Egypt and the United States, represented the opposite party. The conservative party claimed that shariah and Hanafi doctrine should remain the primary source of law. The opposing party, however, cited Article 64, which stated that “... No law shall be repugnant to the basic principle of the sacred religion of Islam..." concern by saying no laws would stand against Islamic shariah. Furthermore, a considerable minority in Afghanistan followed other schools of thought and religions, so the government should consider them as well. ${ }^{41}$ Finally, the article was approved unanimously and, for the first time, secular legislation became 
supreme law, while the Hanafi school of jurisprudence served as a backup in case of a lacuna. This arrangement continues to be accepted until now and is replicated across different constitutions, although the shariah's position as a source of legislation clause (LLC) is also preserved in the constitutions. ${ }^{42}$ Article three of the 2004 Constitution states:

No law shall contravene the tenets and provisions of the holy religion of Islam in Afghanistan. ${ }^{43}$

The 1976 Constitution retained Article 102 of the 1964 Constitution, but after the 1978 coup and collapse of President Dawod's government, the process of secularisation accelerated and, as a result, the role of shariah in the field of law was reduced. In the early days after the coup, the communist regime under the leadership of Noor Muhammad Taraki formed a revolutionary council, which replaced the former government. Under the communist regime, the role of shariah decreased as there was no legislative body; instead, the country was governed by decrees.

Following the invasion of the Soviet Union and the assassination of President Hafizullah Amin on 25 December 1979, Babrak Karmal became the new president. In 1978, Karmal issued the Fundamental Principles of the Democratic Republic of Afghanistan, the fifth constitution of the country. This constitution elevated the authority of the Revolutionary Council as the highest institution of the state. The constitution did not make any reference to Marxism; it declared that in the Democratic Republic of Afghanistan, only official courts (Supreme Court, provincial courts, district courts, and military courts) could adjudicate cases. ${ }^{44}$

Article 56 of the 1978 Constitution applied a concept very similar to Article 130 of the current constitution:

The court has the power to do judicial proceeding and process all civil cases and giving the verdict by the court shall be according to the principle of equality of the citizens in front of the law and the court. During proceeding process, the courts shall apply the laws of Democratic Republic of Afghanistan. If law does not have clarity regarding a case, the courts can make decision according to the Shariah orders, democratic principles, and justice. ${ }^{45}$

Even though most high-ranking officials of the government at the time favoured a secular state, they could not exclude the shariah from the judiciary. 
Nevertheless, there were considerable changes in the text of the article that excluded the Hanafi school of thought and referred generally to the shariah, as well as democratic principles and justice. The majority of Afghan citizens did not receive this shift well and, following the Soviet Union invasion, many Afghans decided to fight against the communist regime.

In 1987, when Dr Najebullah, another leader of the Communist Party, replaced President Babrak Karmal, he enacted a new constitution through the Luya Jirga. In cases of a legal lacuna, the 1987 Constitution revised the 1978 Constitution by removing the phrase 'democratic principles' (but retained the shariah aspect), and gave new powers to judges to make decisions in accordance with shariah principles in a way that they thought just. The 1987 Constitution provided that:

Judges shall apply provisions of this constitution and the laws of the Republic of Afghanistan to cases under consideration. In case of lack of specificity in the law, the court makes a decision according to the provisions of Islamic Sharia, in the way that obtains justice in the best manner. ${ }^{46}$

The 1987 Constitution also excluded the Hanafi school of thought; instead, it drew a bigger circle for judges to apply shariah provisions. However, although judges were provided with a larger source of shariah provisions, there is no record of any case decisions being made according to the shariah under the communist regime.

Mohammad Hashim Kamali observes that,

Except for the 1980 Constitution, which was introduced under the communist party, all the previous constitutions of Afghanistan upheld the Hanafi school of thought as the main source of law in Afghanistan and excluded all other schools 'madhabs' that existed in the country. However, they do not proclaim that all laws must be according to the Hanafi school of thought. ${ }^{47}$

In 2004, the current constitution enacted and modified Article 112 of the 1987 Constitution as below:

In cases under consideration, the courts shall apply provisions of this constitution as well as other laws. If there is no provision in the constitution or other laws about a case, the courts shall, in pursuance of Hanafi jurisprudence, and within the limits set by this constitution, rule in a way that attains justice in the best manner. ${ }^{48}$ 


\section{Judicial Appointment Process in Afghanistan}

Currently, in the judiciary of Afghanistan, there are two categories of judges. The first category includes members of the High Council of the Supreme Court, while the second category includes judges in the primary, appellate courts and other chambers of the Supreme Court.

For judges in the first category, Article 118 of the Constitution requires them to be no less than forty years of age. They must also have not been convicted by a court for crimes against humanity, felony, or deprivation of civil rights and shall not be a member of any political party during their term of duty. The justices must be a citizen of Afghanistan and have higher education in legal studies or Islamic jurisprudence and adequate experience in the judicial system of Afghanistan. ${ }^{49}$ The Supreme Court justices must take an oath in front of the president before they take office; ${ }^{50}$ other judges are not required to take such oaths.

For judges in the second category, the constitution provides the Supreme Court with the power to propose candidates to the president, who then require the latter's final approval. The constitution provides the following:

Judges are appointed at the proposal of the Supreme Court and approval of the president. Appointment, transfer, promotion, punishment and proposals for the retirement of judges, carried out according to provisions of the laws, shall be within the authority of the Supreme Court. To better regulate judicial as well as judicial administrative matters and attain necessary reforms, the Supreme Court shall establish the Office of General Administration of the Judiciary. ${ }^{51}$

It is worth noting that while the executive or legislative branches have the main prerogative to draft laws, the Supreme Court has a special authority to draft laws related to the judiciary. The constitution provides the following:

[t]he proposal for drafting laws shall be made by the government or members of the National Assembly or, in the domain of regulating the judiciary, by the Supreme Court, through the Government.... 52

The constitution requires the qualification and requirement of being a judge to be regulated by law:

With respect to the provisions of this Constitution, statutes related to the formation, authority, as well as proceedings of courts and matters related to judges, shall be regulated by law. ${ }^{53}$ 
The Law on Organization and Jurisdiction of Judiciary defines a judge as a person who carries the certificate of judgment (inselak), ${ }^{54}$ and adjudicates cases and makes judgments in accordance with the law. ${ }^{55}$ The requirements and qualifications for obtaining the judgment certificate are listed in Article 81 of the Law. The conditions listed are as below:

1. Having at least 10 years of Afghanistan citizenship when gaining the certificate.

2. No convictions for any felony or intentional misdemeanour by an authorised court.

3. Having a BA or higher degree from a shariah or law faculty, or a certificate from a public religious secondary school (madrasas) or equivalent institution.

4. Not being infected with any contagious disease or any kind of disability that prevents him/her from normal work.

5. Attained the age of 23 .

6. Successfully completed the Judicial Stage Course.

7. When the number of qualified applicants exceeds the number of vacancies available, the Supreme Court may add more conditions for its admission. Those who already received the judgment certificate before this law is enacted are exempt from the No. 6 clause. ${ }^{56}$

There are several interesting takes from this list. It mentions shariah graduates first, before graduates of law faculties, suggesting priority. In addition, graduates of madrasas ${ }^{57}$ are considered equivalent to those of shariah or law schools in terms of being admitted to the Stage Course.

\section{Short Biography of Supreme Court Justices in the Post-Taliban Judiciary}

It is important to know the educational background of Supreme Court justices and other Supreme Court judges to understand how they deal with legal issues and interpret laws. The Supreme Court of Afghanistan has had nine members since its establishment based on the 2004 Constitution. ${ }^{58}$ Most members of the Supreme Court are shariah graduates or experts in Islamic Law. 


\begin{tabular}{|c|c|c|c|c|}
\hline No. & Name & $\begin{array}{l}\text { Position \& } \\
\text { term }\end{array}$ & Degrees & University \\
\hline 1 & $\begin{array}{l}\text { Mawlawi Fazal } \\
\text { Hadi Shinwari }\end{array}$ & $\begin{array}{l}\text { Chief Justice } \\
(2001-2006)\end{array}$ & Hadith & $\begin{array}{l}\text { Madrasas in } \\
\text { Afghanistan and } \\
\text { Pakistan }\end{array}$ \\
\hline 2 & $\begin{array}{l}\text { Prof. } \\
\text { Abdulsalam } \\
\text { Azimi }\end{array}$ & $\begin{array}{l}\text { Chief Justice } \\
(2006-2015)\end{array}$ & $\begin{array}{l}\text { Shariah (Islamic } \\
\text { Law) }\end{array}$ & $\begin{array}{l}\text { BA from Shariah } \\
\text { Faculty of Kabul } \\
\text { University and } \\
\text { MA from al-Azhar } \\
\text { University in Egypt }{ }^{59}\end{array}$ \\
\hline 3 & $\begin{array}{l}\text { Justice Baha-u- } \\
\text { din Baha }\end{array}$ & $\begin{array}{l}\text { Justice from } \\
(2006-2016)\end{array}$ & $\begin{array}{l}\text { Arabic Studies } \\
\text { and Islamic law }\end{array}$ & $\begin{array}{l}\text { BA from Arabic } \\
\text { Studies Center in } \\
\text { Kabul and MA from } \\
\text { Belford University of } \\
\text { USA }^{60}\end{array}$ \\
\hline 4 & $\begin{array}{l}\text { Justice } \\
\text { Muhammad } \\
\text { Qasim Dost }\end{array}$ & $\begin{array}{l}\text { Justice from } \\
(2006-2010)^{61}\end{array}$ & $\begin{array}{l}\text { Shariah (Islamic } \\
\text { Law) }\end{array}$ & $\begin{array}{l}\text { BA from Shariah } \\
\text { Faculty of Kabul } \\
\text { University }^{62}\end{array}$ \\
\hline 5 & $\begin{array}{l}\text { Justice Ghulam } \\
\text { Nabi Nawayee }\end{array}$ & $\begin{array}{l}\text { Justice from } \\
(2006-2013)^{63}\end{array}$ & $\begin{array}{l}\text { Shariah (Islamic } \\
\text { Law) }\end{array}$ & $\begin{array}{l}\text { BA from Shariah } \\
\text { Faculty of Kabul } \\
\text { University }^{64}\end{array}$ \\
\hline 6 & $\begin{array}{l}\text { Justice } \\
\text { Muhammad } \\
\text { Alim Nasimi }\end{array}$ & $\begin{array}{l}\text { Justice from } \\
(2006-2016)^{65}\end{array}$ & $\begin{array}{l}\text { Shariah (Islamic } \\
\text { Law) }\end{array}$ & $\begin{array}{l}\text { BA from Shariah } \\
\text { Faculty of Kabul } \\
\text { University }^{66}\end{array}$ \\
\hline 7 & $\begin{array}{l}\text { Justice } \\
\text { Muhammad } \\
\text { Omar Babrakzai }\end{array}$ & $\begin{array}{l}\text { Justice from } \\
(2006-2013)\end{array}$ & $\begin{array}{l}\text { Law and } \\
\text { Political } \\
\text { Science }\end{array}$ & $\begin{array}{l}\text { BA from Kabul } \\
\text { Law Faculty and } \\
\text { Diploma from Public } \\
\text { Administration } \\
\text { Institute of France }{ }^{67}\end{array}$ \\
\hline 8 & $\begin{array}{l}\text { Justice } \\
\text { Abdul Rashid } \\
\text { Rashed }\end{array}$ & $\begin{array}{l}\text { Justice from } \\
(2006-2016)^{68}\end{array}$ & $\begin{array}{l}\text { Shariah (Islamic } \\
\text { Law) }\end{array}$ & $\begin{array}{l}\text { BA from Shariah } \\
\text { Faculty of Kabul } \\
\text { University }^{69}\end{array}$ \\
\hline
\end{tabular}




\begin{tabular}{|c|c|c|c|c|}
\hline 9 & $\begin{array}{l}\text { Justice Abdul } \\
\text { Aziz Aziz }\end{array}$ & $\begin{array}{l}\text { Justice from } \\
(2007-2014)^{70}\end{array}$ & $\begin{array}{l}\text { Shariah (Islamic } \\
\text { Law) }\end{array}$ & $\begin{array}{l}\text { Abu Hanifa Madrasa } \\
\text { in Kabul, BA from } \\
\text { Shariah Faculty of } \\
\text { Kabul University, } \\
\text { MA from al-Azhar } \\
\text { University }\end{array}$ \\
\hline 10 & $\begin{array}{l}\text { Justice Zamen } \\
\text { Ali Behsodi }\end{array}$ & $\begin{array}{l}\text { Justice from } \\
(2007-2014)^{72}\end{array}$ & $\begin{array}{l}\text { Shariah (Islamic } \\
\text { Law) }\end{array}$ & $\begin{array}{l}\text { BA from Shariah } \\
\text { Faculty of Kabul } \\
\text { University, MA from } \\
\text { al-Azhar University }^{73}\end{array}$ \\
\hline 11 & $\begin{array}{l}\text { Justice Dr } \\
\text { Abdul Malik } \\
\text { Kamawi }\end{array}$ & $\begin{array}{l}\text { Justice from } \\
(2012-2022)\end{array}$ & $\begin{array}{l}\text { Shariah (Islamic } \\
\text { Law) }\end{array}$ & $\begin{array}{l}\text { Abu Hanifa Madrasa, } \\
\text { BA from Shariah } \\
\text { Faculty at Da'wat-wa- } \\
\text { Jehad University in } \\
\text { Peshawar (Pakistan) } \\
\text { and MA and PhD from } \\
\text { al-Azhar University }{ }^{74}\end{array}$ \\
\hline 12 & $\begin{array}{l}\text { Justice Barat } \\
\text { Ali Matin }\end{array}$ & $\begin{array}{l}\text { Justice from } \\
(2013-2023)^{75}\end{array}$ & $\begin{array}{l}\text { Shariah (Islamic } \\
\text { Law) }\end{array}$ & $\begin{array}{l}\text { BA from Shariah } \\
\text { Faculty at Kabul } \\
\text { University }^{76}\end{array}$ \\
\hline 13 & $\begin{array}{l}\text { Justice Deen } \\
\text { Mohammad } \\
\text { Gran }\end{array}$ & $\begin{array}{l}\text { Justice from } \\
(2014-2024)\end{array}$ & $\begin{array}{l}\text { Shariah (Islamic } \\
\text { Law) }\end{array}$ & $\begin{array}{l}\text { BA from Shariah } \\
\text { Faculty of Kabul } \\
\text { University and } \\
\text { MA from al-Azhar } \\
\text { University }^{77}\end{array}$ \\
\hline 14 & $\begin{array}{l}\text { Justice } \\
\text { Abdul Qader } \\
\text { Adalatkhwa }\end{array}$ & $\begin{array}{l}\text { Justice from } \\
(2013-2023)\end{array}$ & $\begin{array}{l}\text { Shariah } \\
\text { (Islamic Law) } \\
\text { and Family } \\
\text { Law }\end{array}$ & $\begin{array}{l}\text { Takharisan Madrasa } \\
\text { and BA from Shariah } \\
\text { Faculty of Kabul } \\
\text { University, and MA } \\
\text { from Uzbekistan }^{78}\end{array}$ \\
\hline 15 & $\begin{array}{l}\text { Chief Justice } \\
\text { Said Yusuf } \\
\text { Halim }\end{array}$ & $\begin{array}{l}\text { Chief Justice } \\
\text { from (2015- } \\
2025)\end{array}$ & $\begin{array}{l}\text { Law and } \\
\text { Political } \\
\text { Science }\end{array}$ & $\begin{array}{l}\text { BA from Law and } \\
\text { Political Science } \\
\text { Faculty of Kabul } \\
\text { University and Masters } \\
\text { Degree from Islamic } \\
\text { Azad University of } \\
\text { Iran, Kabul Branch. }\end{array}$ \\
\hline
\end{tabular}




\begin{tabular}{|l|l|l|l|l|}
\hline 16 & $\begin{array}{l}\text { Justice Abdul } \\
\text { Hasib Ahadi }\end{array}$ & $\begin{array}{l}\text { Justice from } \\
(2016-2026)\end{array}$ & $\begin{array}{l}\text { Shariah (Islamic } \\
\text { Law) }\end{array}$ & $\begin{array}{l}\text { BA from Shariah } \\
\text { Faculty of Kabul } \\
\text { University }\end{array}$ \\
\hline 17 & $\begin{array}{l}\text { Justice } \\
\text { Mohammad } \\
\text { Zamam Sangari }\end{array}$ & $\begin{array}{l}\text { Justice from } \\
(2016-2026)\end{array}$ & $\begin{array}{l}\text { Shariah (Islamic } \\
\text { Law) }\end{array}$ & $\begin{array}{l}\text { BA from Shariah } \\
\text { Faculty of Kabul } \\
\text { University }\end{array}$ \\
\hline
\end{tabular}

Based on the above, since the year 2004, all Supreme Court justices have had an Islamic law background, except the current Chief Justice Halim and Justice Babrakzai, whom both have a background in law and political science. This reveals the dominant role of shariah graduates in the Afghan judiciary and can perhaps shed some light on a possible trend in interpreting laws and decisionmaking.

\section{Judicial Training in Afghanistan}

Apart from the Supreme Court Justices, all judges in Afghanistan must fulfil certain requirements provided by the law. One of the main qualifications is to have a degree from either a shariah or law faculty, or from a madrasa. Afghanistan has a parallel legal education system. In almost all public and private universities, there are two institutions that train judges and lawyers: a law and political science faculty and a shariah faculty. The Supreme Court also admits graduates of madrasas to the Supreme Court Stage Course. ${ }^{80}$

Other requirements include the successful completion of the Supreme Court Judiciary Training Program (Stage Course). The Stage Course was established by the Supreme Court in 1968, to provide judicial training for shariah, law, and madrasa graduates. Since the establishment of the Stage Course, a majority of judges now have shariah and Islamic law backgrounds. The following statistics, however, show a considerable difference in the admission rate between shariah, law, and madrasa graduates. 


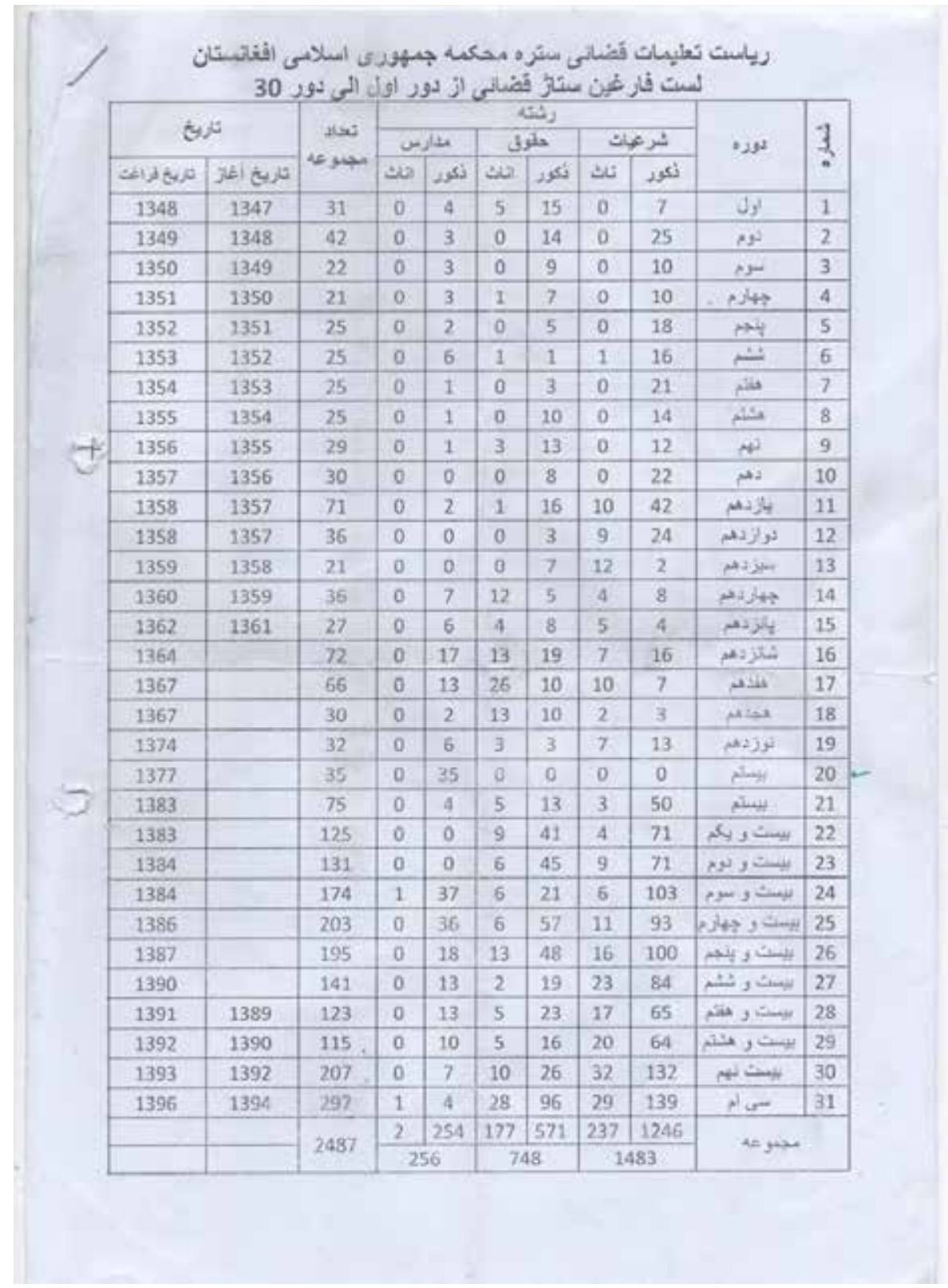

Original Image of the List of Graduates from the Supreme Court Stage Course 


\begin{tabular}{|c|c|c|c|c|c|c|c|c|c|}
\hline \multicolumn{10}{|c|}{$\begin{array}{l}\text { Department of Judicial Training of the Supreme Court } \\
\text { List of the Graduates from the Supreme Court Stage Course Since its } \\
\text { Establishment in } 1968\end{array}$} \\
\hline \multirow[b]{2}{*}{ Round } & \multicolumn{2}{|c|}{ Sharia } & \multicolumn{2}{|c|}{ Law } & \multicolumn{2}{|c|}{ Madrasa } & \multirow[b]{2}{*}{ Score } & \multirow[b]{2}{*}{ Start Date } & \multirow[b]{2}{*}{ End Date } \\
\hline & Male & Female & Male & Female & Male & Female & & & \\
\hline $1 \mathrm{st}$ & 7 & 0 & 15 & 5 & 4 & 0 & 31 & $1347 / 1968$ & $1348 / 1969$ \\
\hline 2nd & 25 & 0 & 14 & 0 & 3 & 0 & 42 & $1348 / 1969$ & $1349 / 1970$ \\
\hline $3 \mathrm{rd}$ & 10 & 0 & 9 & 0 & 3 & 0 & 22 & $1349 / 1970$ & $1350 / 1971$ \\
\hline 4 th & 10 & 0 & 7 & 1 & 3 & 0 & 21 & $1350 / 1971$ & $1351 / 1972$ \\
\hline 5 th & 18 & 0 & 5 & 0 & 2 & 0 & 25 & $1351 / 1972$ & $1352 / 1973$ \\
\hline 6th & 16 & 1 & 1 & 1 & 6 & 0 & 25 & $1352 / 1973$ & $1353 / 1974$ \\
\hline 7th & 21 & 0 & 3 & 0 & 1 & 0 & 25 & $1353 / 1974$ & $1354 / 1975$ \\
\hline 8 th & 14 & 0 & 10 & 0 & 1 & 0 & 25 & $1354 / 1975$ & $1355 / 1976$ \\
\hline 9th & 12 & 0 & 13 & 3 & 1 & 0 & 29 & $1355 / 1976$ & $1356 / 1977$ \\
\hline 10th & 22 & 0 & 8 & 0 & 0 & 0 & 30 & $1356 / 1977$ & $1357 / 1978$ \\
\hline 11th & 42 & 10 & 16 & 1 & 2 & 0 & 71 & $1357 / 1978$ & $1358 / 1979$ \\
\hline 12 th & 24 & 9 & 3 & 0 & 0 & 0 & 36 & $1357 / 1978$ & $1358 / 1979$ \\
\hline 13th & 2 & 12 & 7 & 0 & 0 & 0 & 21 & $1358 / 1979$ & $1359 / 1980$ \\
\hline 14 th & 8 & 4 & 5 & 12 & 7 & 0 & 36 & $1359 / 1980$ & $1360 / 1981$ \\
\hline 15 th & 4 & 5 & 8 & 4 & 6 & 0 & 27 & $1361 / 1982$ & $1362 / 1983$ \\
\hline 16th & 16 & 7 & 19 & 13 & 17 & 0 & 72 & & $1364 / 1985$ \\
\hline 17 th & 7 & 10 & 10 & 26 & 13 & 0 & 66 & & $1367 / 1988$ \\
\hline 18 th & 3 & 2 & 10 & 13 & 2 & 0 & 30 & & $1367 / 1988$ \\
\hline 19th & 13 & 7 & 3 & 3 & 6 & 0 & 32 & & $1374 / 1995$ \\
\hline 20th & 0 & 0 & 0 & 0 & 35 & 0 & 35 & & $1377 / 1998$ \\
\hline $21 \mathrm{st}$ & 50 & 3 & 13 & 5 & 4 & 0 & 75 & & $1383 / 2004$ \\
\hline 22nd & 71 & 4 & 41 & 9 & 0 & 0 & 125 & & $1383 / 2004$ \\
\hline $23 \mathrm{rd}$ & 71 & 9 & 45 & 6 & 0 & 0 & 131 & & $1384 / 2005$ \\
\hline 24th & 103 & 6 & 21 & 6 & 37 & 1 & 174 & & $1384 / 2005$ \\
\hline 25 th & 93 & 11 & 57 & 6 & 36 & 0 & 203 & & $1386 / 2007$ \\
\hline 26th & 100 & 16 & 48 & 13 & 18 & 0 & 195 & & $1387 / 2008$ \\
\hline 27 th & 84 & 23 & 19 & 2 & 13 & 0 & 141 & & $1390 / 2011$ \\
\hline 28th & 65 & 17 & 23 & 5 & 13 & 0 & 123 & $1389 / 2010$ & $1391 / 2012$ \\
\hline 29th & 64 & 20 & 16 & 5 & 10 & 0 & 115 & $1390 / 2011$ & $1392 / 2013$ \\
\hline
\end{tabular}




\begin{tabular}{|c|c|c|c|c|c|c|c|c|c|}
\hline 30th & 132 & 32 & 26 & 10 & 7 & 0 & 207 & $1392 / 2013$ & $1393 / 2014$ \\
\hline $31 \mathrm{st}$ & 139 & 29 & 96 & 28 & 4 & 1 & 297 & $1394 / 2015$ & $1396 / 2017$ \\
\hline Total & \multicolumn{2}{|c|}{ Shariah 1483} & Law & & \multicolumn{2}{|c|}{ Madrasa 256} & $\begin{array}{l}\text { Final } \\
\text { total } \\
2487\end{array}$ & & \\
\hline
\end{tabular}

Looking at the total number of participants in the Judiciary Stage Training programme, the highest number (1483 out of 2487) were graduates of shariah faculties, the second-highest (784 out of 2487) were graduates of law faculties, and the least number (256 out 2487) were madrasa graduates. Since the main courses in both shariah and madrasa institutions focus on classical Islamic sources, this means that more than two-third of judges in Afghanistan have a background in Islamic law and shariah.

The graph below indicates the gradual increase in the number of shariah graduates in the Supreme Court Judiciary Training Course since its establishment.

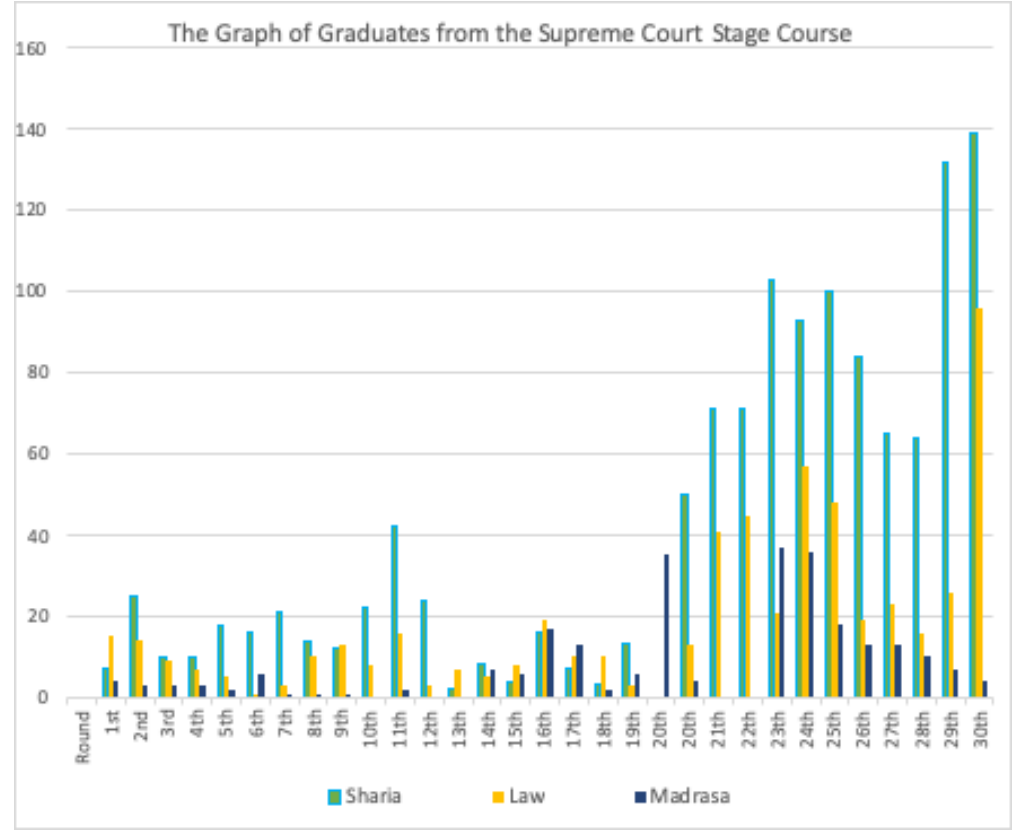


The diagram shows that there are increases and decreases in the number of graduates from different institutions admitted to the Supreme Court stagetraining course. It shows that, at the beginning, more law graduates were admitted, but graduates from shariah faculties gradually gained the majority and then maintained it. Overall, graduates from shariah faculties and madrasas represent the largest majority in the Afghan judiciary.

\section{Conclusion and Policy Recommendations}

The shariah, particularly the Hanafi school of thought, has played a significant role in the judicial system of Afghanistan. It has been the main source of law for many cent uries; even today Islamic scholars continue to play a significant role in the Afghan judicial system. Provided below are several policy recommendations that could enhance legal education and judicial training in Afghanistan:

- Opinions by modern Islamic scholars should be included in the shariah legal curriculum of both shariah faculties and madrasas, in addition to the traditional use of classical Arabic texts.

- The legal curriculum should be revised to close the gap between graduates of law faculties and shariah faculties. Due to the parallel legal education system in Afghanistan, law faculties mostly focus on modern law courses, while shariah faculties focus on classical Arabic texts. Having well-qualified judges requires a modern and inclusive legal curriculum.

- The Supreme Court should develop a well-equipped Islamic law research centre and capacity building programmes for judges. Areas of research should include new legal issues and should emulate the Continuing Legal Education (CLE) programmes. The research centre is also expected to provide new solutions through comparative studies and re-examine matters in light of shariah principles.

- Important Arabic texts should be translated into local Afghan languages. This will help Afghan judges, particularly those who graduated from law schools, have access to the main sources of shariah law in Afghanistan. 


\section{Notes}

* Lutforahman Saeed, LLM, PhD. Assistant Professor at the Islamic Law Faculty, Kabul University. Editor in chief, Journal of Afghan Legal Studies.

1. Madhhab (Arabic: مذهب) is an Arabic term that refers to an Islamic school of thought.

2. Azizudeen Wakily Popalzaey, Dar al-Qaza in Afghanistan: From the Beginning of Islam Until Republic Era (Kabul: Islamic Research Center, 1990), 41.

3. Ibid., 47.

4. Said Mahmoudi, 'The Shariah in the New Afghan Constitution: Contradiction or Compliment,' Max-Planck Foundation for Peace and Rule of Law, 871. Available at: https://www.zaoerv.de/64_2004/64_2004_4_a_867_880.pdf

5. In Afghanistan, there are two institutions that train legal experts: 1) shariah faculties, and 2) law and political science faculties. A majority of judges have shariah backgrounds, and most of the law graduates go to the Attorney General Office as prosecutors or defense attorneys. The legal educational and related institutions in Afghanistan will be discussed in more detail later.

6. Azizudeen, Dar al-Qaza in Afghanistan, 47-8.

7. The Constitution of Afghanistan (1952) Art. 1.

8. Interview with Judge Salam Qazizadah, former chief judge of the appellate court of Kabul, who made decisions regarding the Parwiz Kambakhsh case at Kabul appellate court (9 August 2015).

9. Interviews with Prof. Abdul Aziz, a member of the Supreme Court of Afghanistan and former dean of the Kabul Shariah Faculty, and some Kabul University Shariah Faculty members (15 August 2019).

10. Sultan Mahmood Gaznawi ruled most of south and central Asia from Ghazni city for many years.

11. Hazrat Gul Hussami, History of Judiciary in Afghanistan (Kabul: Saeed Publications, 2009), 24.

12. Ibid., 26.

13. Ibid., 28.

14. https://supremecourt.gov.af/fa/page/620/2958 (Accessed on: 12 May 2015).

15. Hussami, History of Judiciary in Afghanistan, 32.

16. The History of Ministry of Justice of Afghanistan. Available at https://moj. gov.af/fa/page/7943/16571664 (Accessed on: 7 April 2014).

17. Meer Ghulam Mohammad Ghubaar, Afghanistan Dar Masir-e Taarikh (Kabul: Musen Publications, 2012), 374.

18. The History of Ministry of Justice of Afghanistan. Available at https://moj. gov.af/fa/page/7943/16571664 (Accessed on: 7 April 2014).

19. Azizudeen, Dar al-Qaza in Afghanistan, 174.

20. Hussami, History of Judiciary in Afghanistan, 32-7.

21. Thomas Barfield, Afghan Customary Law and its Relationship to Formal Judicial Institutions (Washington: Boston University, 2003), 1.

22. Hussami, History of Judiciary in Afghanistan, 37. 
23. Mohammad Ashraf Ghani, 'Disputes in a Court of Sharia, Kunar Valley, Afghanistan, 1885-1890,' International Journal of Middle East Studies 15, no. 3 (1983): 354.

24. Sirat, 'Shariah and Islamic Education in Modern Afghanistan,' 217-9,

25. Asas Al-Quzzat was the first codified statute drafted in 136 articles.

26. Ashraf Ghani, 'Disputes in a Court of Sharia,' 354.

27. Ahmad Jan Alokozai, Asas Al-Quzzat (Kabul: Darul Saltanah Publication, 1885), Art. 26.

28. Ibid., Art. 8.

29. The First Constitution of Afghanistan, Nezaam Namah Assaasi Doulat Aleyah Afghanistan, 1923, Art. 2.

30. Ibid., Art. 6.

31. Ibid., Art. 55.

32. Tamassuk al-Quddat al-Amaniyah was Afghanistan's first criminal code. Written by a famous scholar, Mawlawi Abdul Wasi, it was reviewed by chief justices along with a group of famous judges, including appeal court and primary court judges. This book was adopted and published during King Amanullah's reign in 1921. In contrast to other Hanafi sources, this book is in Dari and composed of 14 chapters and 1113 articles. In this book, each article refers to a Hanafi text; no other schools of jurisprudence are named.

33. Abdulwase, Tamassuk Al Quzzat Al-Amaniyah, 2.

34. Ibid., 3 .

35. The First Constitution of Afghanistan, Art. 1.

36. Ibid., Art. 87.

37. The Constitution of Afghanistan (1964) Art. 69.

38. Louis Dupree, Afghanistan (Princeton: Princeton University Press, 2014), 582.

39. Ibid., Art. 102. Translation by Louis Dupree (p.583).

40. The Constitution of Afghanistan (1964) Art. 64.

41. Meer Muhammad Sediq Farhang, Afghanistan during the Last Five Centuries (Qum: Isma-elyan Publications, 1992) vol. 1, 545.

42. LLC is a very important topic in Afghanistan, but needs to be discussed in a separate research paper.

43. The Constitution of Afghanistan (2004) Art. 3.

44. The Fundamental Principles of the Democratic Republic of Afghanistan 1978, Art. 54.

45. Ibid., Art. 56.

46. The Constitution of Afghanistan (1987) Art. 112.

47. Mohammad Hashim Kamali, Law in Afghanistan: A Study of Constitutions, Matrimonial Law and the Judiciary (Leiden: Brill Academic Publisher, 1997), 175.

48. The Constitution of Afghanistan (2004) Art.130.

49. Ibid., Art. 118.

50. Ibid., Art. 119, "In the name of God, the Most Gracious, Most Merciful, I swear in the name of God Almighty to attain justice and righteousness in accordance with tenets of the Holy religion of Islam, provisions of this Constitution as well as other laws of Afghanistan, and to execute the judicial duty with utmost 
honesty, righteousness and impartiality."

51. Ibid., Art. 132.

52. Ibid., Art. 92.

53. Ibid., Art. 123.

54. Inselak is a certificate signed by the President that officially authorises judges to adjudicate cases in court.

55. Law on Organization and Jurisdiction of Judiciary, Art. 4, clause 16.

56. Law on Organization and Jurisdiction of Judiciary (2013) official Gazette No 1109, Art. 81.

57. Madrasa is a religious high school focused on classical Islamic sources.

58. The Constitution of Afghanistan (2004) Art. 117.

59. N. A, 'Sharaiat,' Journal of Kabul Shariah Faculty 2, no. 7-8 (2013): 207.

60. Biography of the Supreme Court Members. Available at: http://elections. pajhwok.com/en/content/biography-supreme-court-members (Accessed on: 29 January 2019.

61. Ibid.

62. Journal of Kabul Shariah Faculty 2, no. 7-8 (2013): 209.

63. Biography of the Supreme Court Members. Available at http://elections. pajhwok.com/en/content/biography-supreme-court-members (Accessed on: 29 January 2019.

64. Journal of Kabul Shariah Faculty 2, no. 11 (2014): 141.

65. Biography of the Supreme Court Members. Available at http://elections. pajhwok.com/en/content/biography-supreme-court-members (Accessed on: 29 January 2019.

66. Journal of Kabul Shariah Faculty 2, no. 16-17 (2016): 230.

67. Biography of the Supreme Court Members. Available at http://elections. pajhwok.com/en/content/biography-supreme-court-members (Accessed on: 29 January 2019.

68. Ibid.

69. Journal of Kabul Shariah Faculty 2, no. 7-8 (2013): 210.

70. Biography of the Supreme Court Members. Available at http://elections. pajhwok.com/en/content/biography-supreme-court-members (Accessed on: 29 January 2019.

71. Journal of Kabul Shariah Faculty 2, no. 7-8 (2013): 208.

72. Biography of the Supreme Court Members. Available at http://elections. pajhwok.com/en/content/biography-supreme-court-members (Accessed on: 29 January 2019).

73. Journal of Kabul Shariah Faculty 2, no. 7-8 (2013): 207.

74. http://supremecourt.gov.af/en/page/ff614/619/44457 (Accessed on: 7 February 2019).

75. http://supremecourt.gov.af/fa/page/ff614/619/44458 (Accessed on: 7 February 2019).

76. Journal of Kabul Shariah Faculty 2, no. 18 (2016): 131.

77. Journal of Kabul Shariah Faculty 2, no. 11 (2016): 137.

78. http://supremecourt.gov.af/fa/page/ff614/619/44459 (Accessed on: 7 February 2019).

79. http://supremecourt.gov.af/page/ff614 (Accessed on: 7 April 2019). 
80. The Supreme Court has a special judiciary-training programme called Judiciary Training Stage Course. The Shariah, Law, and Madrasa graduates attend a competitive entrance exam; only 100 people get admission to the programme. 